\title{
Mobile Application Get Nurse Sebagai Platform Digital Pelayanan Kesehatan Masa Pandemi Covid-19
}

\author{
Oleh Soleh ${ }^{1}$, Trie Mayhera Sabalidowati ${ }^{2}$, Praditya Aliftiar ${ }^{3}$ \\ 1,2,3 Program Studi Sistem Informasi Universitas Raharja \\ Email : ${ }^{1}$ oleh.soleh@ raharja.info, ${ }^{* 2}$ trie.mayhera@ raharja.info, ${ }^{3}$ praditya.aliftiar@ raharja.info
}

\begin{abstract}
Abstrak
Pada tahun 2020, seluruh dunia dilanda wabah COVID-19 (coronavirus diseases-19). Hal ini menciptakan kebiasaan baru dan mengubah pola kehidupan masyarakat. Banyak masyarakat yang cemas akan tertular virus jika pergi ke tempat seperti klinik ataupun rumah sakit untuk mendapatkan pelayanan kesehatan. Masyarakat pun menjadi lebih waspada dan mencari alternatif pelayanan kesehatan yang lebih aman. Atas keresahan tersebut penulis membuat sebuah platform digital pelayanan kesehatan yang dapat diakses masyarakat secara mudah dan cepat. Penelitian ini bertujuan untuk membuat sebuah platform digital guna menjembatani masyarakat yang membutuhkan pelayanan kesehatan tanpa harus keluar rumah dengan para tenaga kesehatan khususnya perawat. Business Model Canvas (BMC) digunakan oleh penulis sebagai metode analisa sistem. Pemodelan sistem menggunakan Unified Modelling Languange $(U M L)$. Untuk merancang sistem digunakan kotlin sebagai bahasa program dengan arsitektur MVP (Model-View-Presenter) dan mysql sebagai database. Serta metode Usability Testing digunakan untuk menguji sistem. Hasil dari penelitian ini adalah terciptanya platform mobile yang dapat membantu masyarakat kapanpun dan dimanapun mereka membutuhkan pelayanan kesehatan dengan mudah.
\end{abstract}

Kata kunci: Virus corona, Homecare, Platform digital, Kotlin, Usability testing

\begin{abstract}
In 2020, the whole world was hit by an epidemic of COVID-19 (coronavirus diseases-19). This creates new habits and changes the pattern of people's lives. Many people are worried that they will catch the virus if they go to places such as clinics or hospitals to get health services. The community has become more vigilant and is looking for safer alternative health services. Due to this concern, the authors created a digital platform for health services that can be accessed by the public easily and quickly. This study aims to create a digital platform to bridge people who need health services without having to leave the house with health workers, especially nurses. The Business Model Canvas (BMC) is used by the author as a system analysis method. System modeling uses the Unified Modeling Language (UML). To design the system, Kotlin is used as a programming language with an MVP (Model-View-Presenter) architecture and MySQL as a database. As well as the Usability Testing method used to test the system. The result of this research is the creation of a mobile platform that can easily help people whenever and wherever they need health services.
\end{abstract}

Keywords: Coronavirus, Homecare, Digital platform, Kotlin, Usability testing 


\section{PENDAHULUAN}

Tahun 2020 menjadi tahun tantangan bagi umat manusia, di tahun ini seluruh dunia dilanda sebuah wabah COVID-19 (coronavirus diseases-19). COVID-19 merupakan salah satu virus menular yang disebabkan oleh coronavirus. Di Indonesia sendiri jumlah kasus positif corona mengalami penambahan setiap harinya. Menurut portal berita harian kompas.com pada tanggal 11 september 2020, penambahan tersebut menyebabkan kasus Covid-19 di Indonesia bertambah menjadi 210.940 orang, terhitung sejak kasus pertama pada 2 Maret 2020 [1]. Sejak adanya wabah virus corona ini, membuat masyarakat memprioritaskan kesehatannya. Namun, disisi lain masyarakat juga khawatir untuk melakukan konsultasi ke rumah sakit, klinik ataupun rumah sakit. Masyarakat pun menjadi lebih waspada dan mencari alternatif pelayanan kesehatan yang lebih aman dan nyaman.

Atas keresahan pada masalah di atas, maka dibutuhkan sebuah platform digital layanan kesehatan yang bisa membatasi diri dari kegiatan diluar rumah, dan memudahkan masyarakat khususnya yang membutuhkan pelayanan kesehatan. Terutama perawatan dan penjagaan bisa menikmati layanan kesehatan dengan nyaman di rumah (homecare) tanpa harus pergi ke rumah sakit atau praktek dokter.

\section{METODE PENELITIAN}

\subsection{Metode Pengumpulan Data}

Dalam proses pengumpulan data, penulis mengunakan metode-metode berikut :

\section{a. Observasi}

Dengan metode ini, dilakukan pengamatan secara langsung untuk melihat permasalahan yang sedang terjadi saat ini.

\section{b. Wawancara}

Penulis melakukan sesi wawancara secara langsung kepada beberapa narasumber seperti masyarakat yang membutuhkan pelayanan kesehatan khususnya dalam hal perawatan dan tenaga kesehatan, terutama perawat untuk memperoleh data serta informasi terhadap aplikasi layanan kesehatan yang akan dibuat.

\section{c. Studi Pustaka}

Penulis juga mendapatkan data dan informasi tambahan dengan bersumber dari buku, internet dan sebagainya. Sehingga dapat menjadi referensi bagi penulis.

\subsection{Metode Analisa}

\section{a. Analisa Business Model Canvas (BMC)}

Merupakan suatu bisnis model yang dipresentasikan kedalam bentuk kanvas lukisan sehingga dapat dipahami dengan mudah. Pada BMC Terdapat 9 blok yang mempunyai fungsi masing-masing [2], meliputi customer segments, value proposition, channels, customer relationship, revenue stream, key resource, key activities, key partnership, dan cost structure.

\subsection{Metode Pemodelan}

a. Unified Modelling Language (UML)

Penulis menggunakan UML yaitu bahasa yang digunakan dalam memvisualisasikan, menspesifikasikan, merancang, dan mendokumentasikan suatu 
software berbasis object [3]. Untuk merancang $U M L$ peneliti menggunakan software flowchart maker \& online diagram.

\subsection{Metode Testing}

a. Usability Testing

Merupakan proses pengujian atau testing yang melibatkan user untuk menggunakan produk guna mencapai aspek efisiensi, efektivitas dan kepuasan user [4]. Dari pengujian yang dilakukan nantinya dapat diketahui apakah sistem yang telah dibuat sudah memenuhi fungsionalitas / belum.

\section{LITERATURE REVIEW}

Berikut adalah penelitian terdahulu yang sudah dilakukan dan memiliki korelasi mengenai platform digital pelayanan kesehatan, yaitu :

1. Penelitian yang dilakukan oleh Harsiti., dkk (2016) dengan judul "Rancang Bangun Aplikasi E-Health Untuk Peningkatkan Pelayanan Kesehatan Pada Puskesmas Kibin". Permasalahan yang dibahas yaitu banyaknya waktu pasien yang terbuang untuk melakukan pendaftaran dan pemeriksaan kesehatan. Sehingga dikembangkan ehealth agar pelayanan pada Puskesmas Kibin meningkat. Metode survey digunakan dalam penelitian ini, analisa dengan metode $U M L$ serta peracangan dengan bahasa PHP dan Dreamweaver. Penelitian ini menghasilkan aplikasi e-health yang dapat meningkatkan layanan kesehatan dan memudahkan pasien dalam memperoleh informasi. [5]

2. Penelitian yang dilakukan oleh Sari., dkk (2020) dengan judul "Rancang Bangun Aplikasi Homecare Ibu Dan Anak Berbasis Android". Permasalahan yang dibahas yaitu banyaknya orangtua yang tidak mempunyai waktu luang untuk melakukan perawatan kepada anaknya. Sehingga dirancang aplikasi yang dapat memberikan pelayanan kepada Ibu dan Anak. Hasil dari penelitian ini yaitu aplikasi berbasis android yang dapat mempermudah orangtua dalam mendapatkan pelayanan perawatan Ibu dan anak. [6]

3. Penelitian yang dilakukan oleh Sambuaga, J.H., dkk (2017) dengan judul "Perancangan E-Health Kota Cerdas". Penelitian ini membahas pengembangan $E$ health yang menjadi bagian dari konsep smartcity, dimulai dari pelayanan pasien rawat jalan, rawat inap dan lainnya. Metode EAP (Enterprise Architecture Planning) digunakan dalam merancang aplikasi. Tujuan dari penelitian ini untuk menghasilkan rancangan arsitektur aplikasi e-health yang dapat mempermudah penentuan dari model aplikasi yang akan dikembangkan. [7]

4. Penelitian yang dilakukan oleh Istifada, R., dkk (2017) dengan judul "Pemanfaatan Teknologi Telehealth Pada Perawat Di Layanan Homecare". Permasalahan yang dibahas yaitu sulitnya akses pelayanan kesehatan didaerah perbatasan sehingga menyebabkan kurangnya tingkat kesadaran masyarakat mengenai kesehatan. Peneliti menggunakan metode literature review yang terfokus kepada pemanfaatan $e$-health. [8]

\section{HASIL DAN PEMBAHASAN}

\subsection{Analisa Sistem}

Tahap analisa dilakukan sebelum perancangan suatu sistem. Penulis menggunakan metode Business Model Canvas dalam menganalisa sistem yang akan dibuat, seperti gambar dibawah ini : 


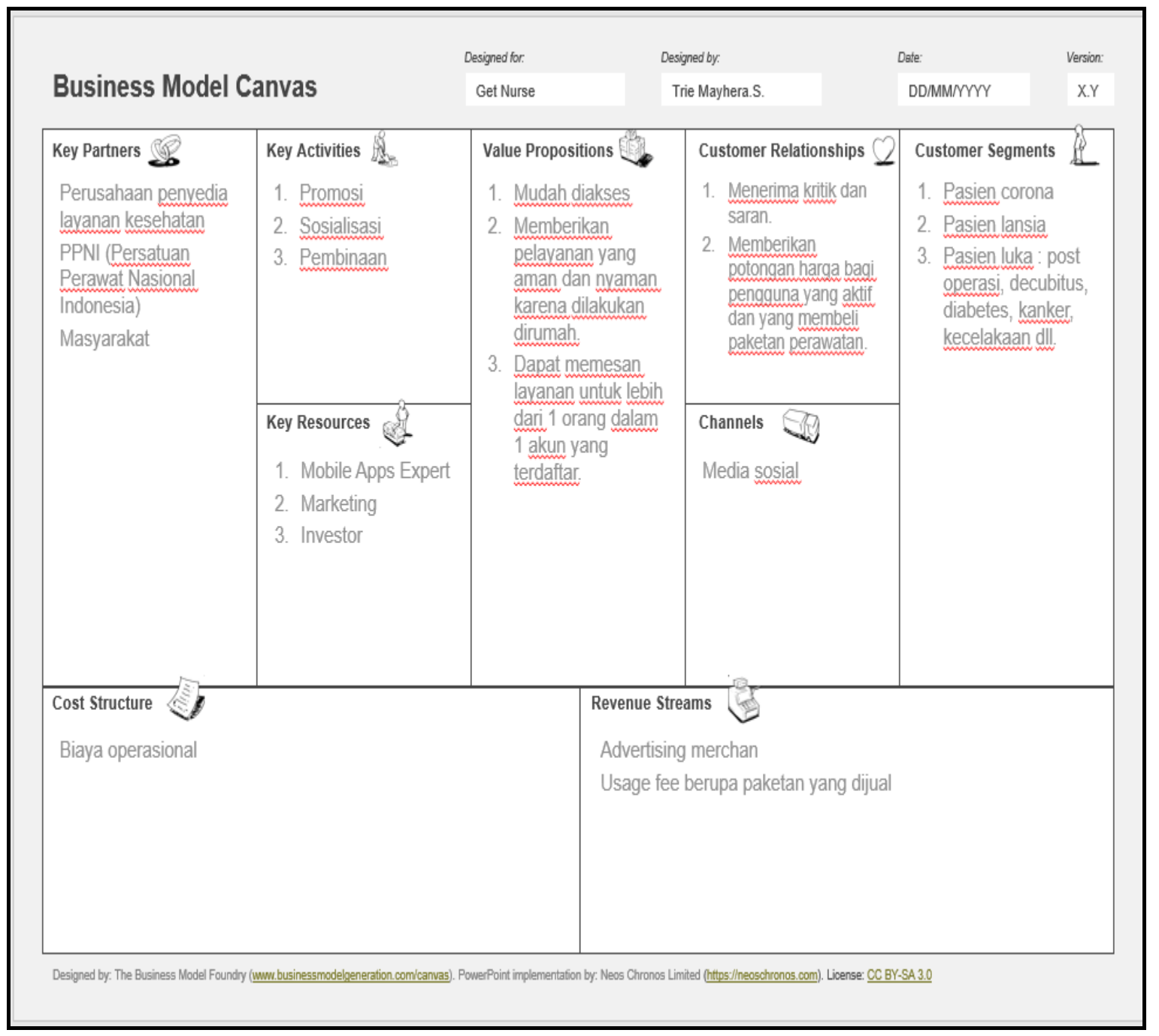

Gambar 1. Analisa Business Model Canvas (BMC)

\subsection{Rancangan Diagram Aplikasi Get Nurse}

a. Use Case Diagram 


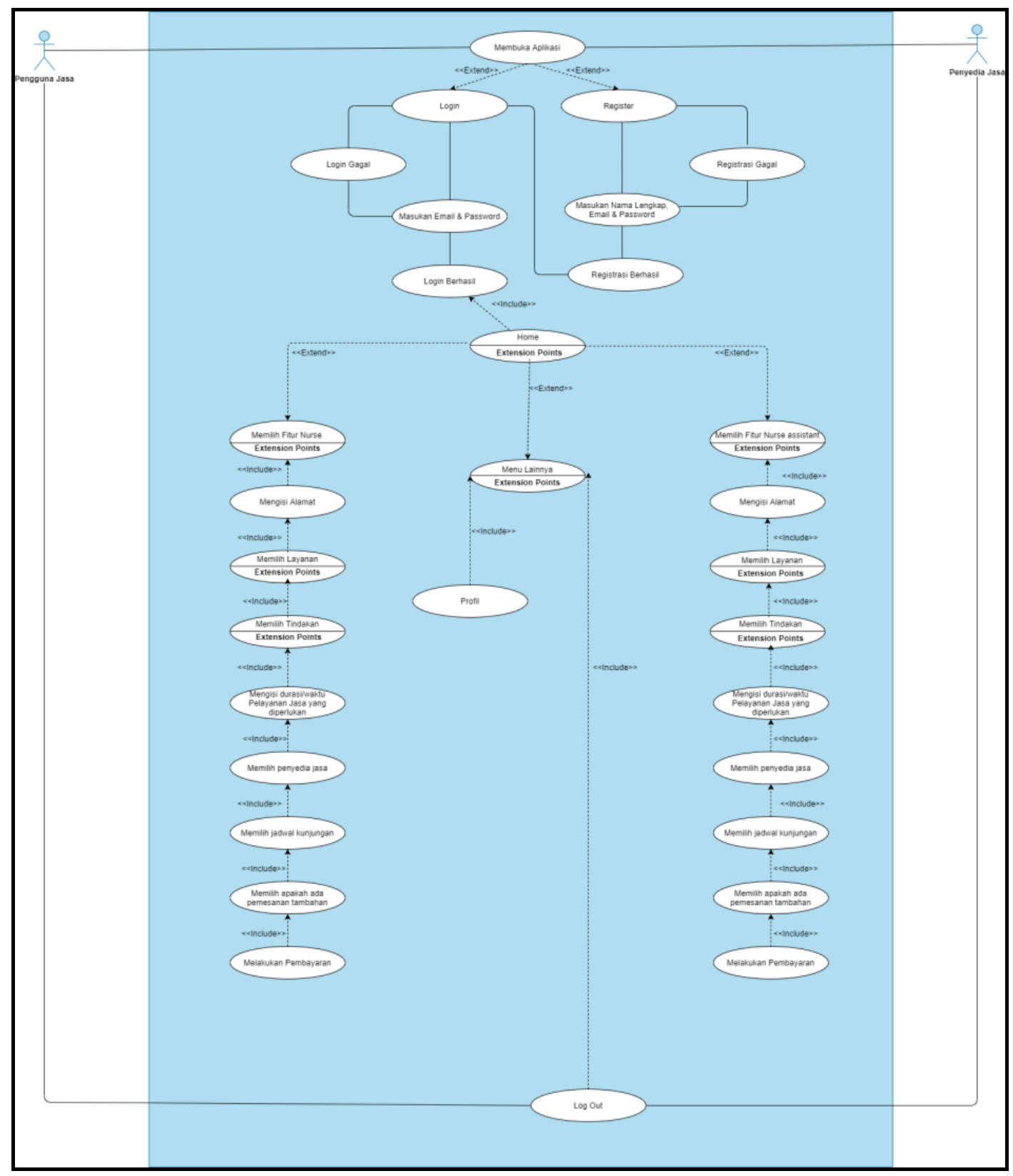

Gambar 2. Use Case Diagram Aplikasi Get Nurse

Pada Use case Diagram diatas terdapat:

a) Terdapat 2 aktor yaitu Pengguna jasa dan Penyedia jasa.

b) Terdapat 31 usecase yaitu Membuka aplikasi, Register, Registrasi gagal, Masukan nama lengkap email dan password, Registrasi berhasil, Login, Login gagal, Masukkan username \& password, Login berhasil, Home, Memilih fitur nurse, Memilih fitur nurse asisten, Menu lainnya, Mengisi alamat, Memilih layanan, Memilih tindakan, Mengisi durasi/waktu, Memilih penyedia jasa, Memilih jadwal kunjungan, Memilih apakah ada pesanan tambahan, Melakukan pembayaran dan Logout. 


\section{b. Activity Diagram}

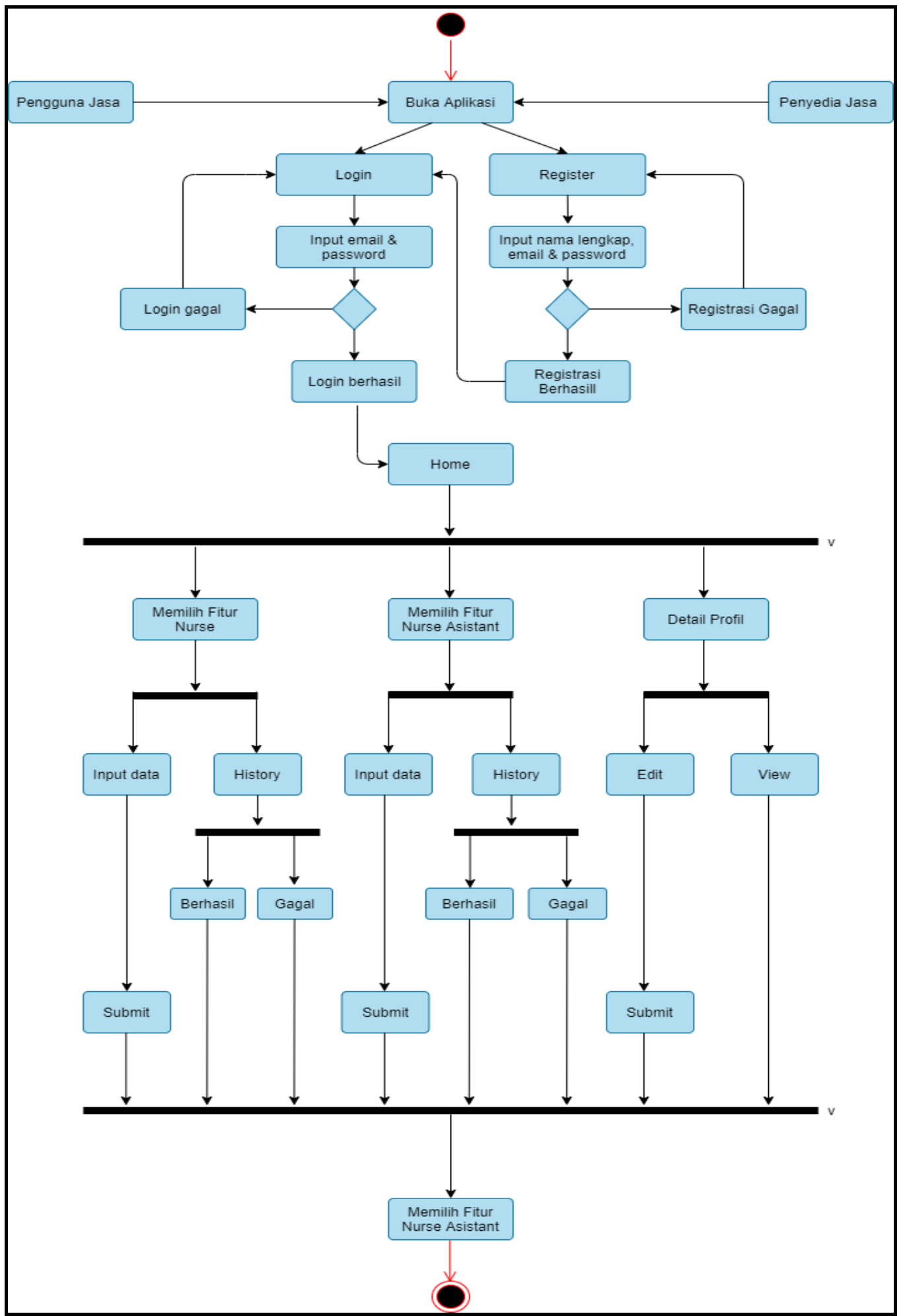

Gambar 3. Activity Diagram Aplikasi Get Nurse

Pada Activity Diagram diatas terdapat:

a) 1 Initial Node, untuk mengawali suatu kegiatan 
b) 27 Action, yang akan mengeksekusi suatu aksi

c) 2 Decision Node yang merupakan kondisi percabangan berisi ya/tidak

d) 7 Fork Node, pemecah satu aliran menjadi beberapa aliran

\section{c. Sequence Diagram}

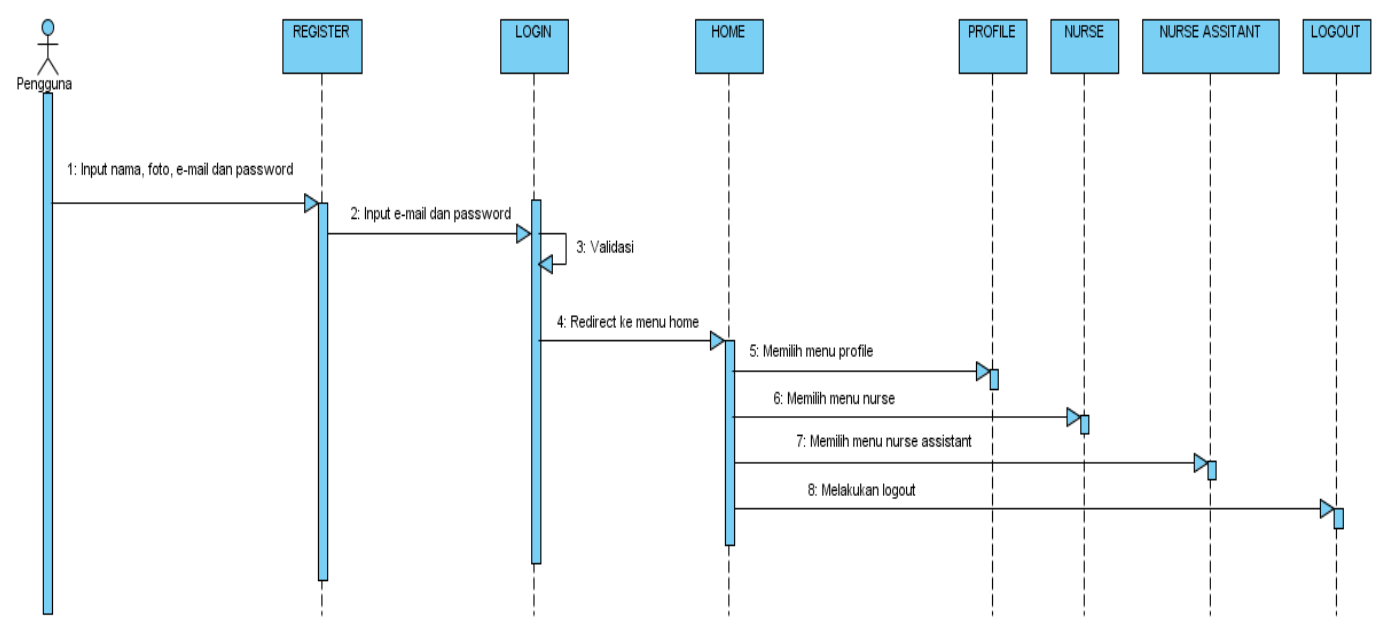

Gambar 4. Sequence Diagram Aplikasi Get Nurse

Pada Sequence Diagram diatas terdapat:

a) 1 aktor, yaitu Pengguna Jasa.

b) 7 lifeline, yaitu Register, Login, Home, Profile, Nurse, Nurse Assistant dan Logout.

c) 8 pesan, yang digunakan untuk berkomunikasi antar object.

\subsection{Rancangan Aplikasi Get Nurse}

Langkah yang dilakukan selanjutnya yaitu merancang aplikasi dengan menggunakan bahasa program Kotlin dan MYSQL sebagai database sistem. Berikut adalah tampilan dari aplikasi get nurse :

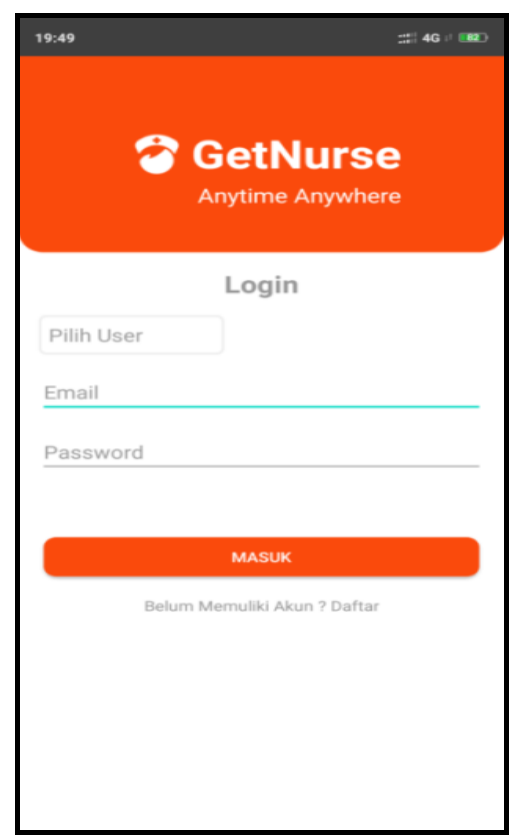

Gambar 5 Halaman Login 
Pada gambar 5 diatas, user dapar memilih 2 role yaitu pasien atau perawat. User harus menginput email dan password untuk masuk kedalam aplikasi. Jika user belum mempunyai akun maka klik daftar untuk menuju kehalaman register.

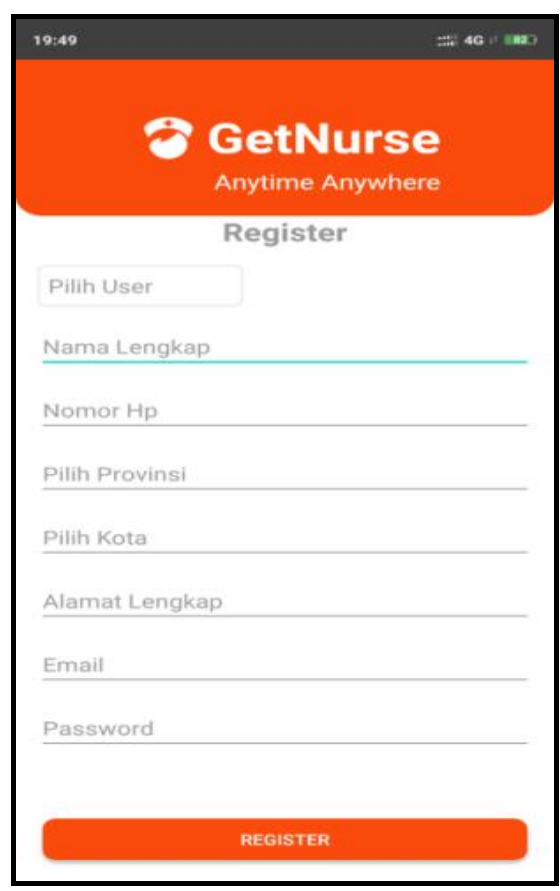

Gambar 6 Halaman Register

Pada gambar 6 diatas, user harus mengisi beberapa data yang diperlukan untuk registrasi akun. Jika berhasil maka akan langsung diarahkan kehalaman login.

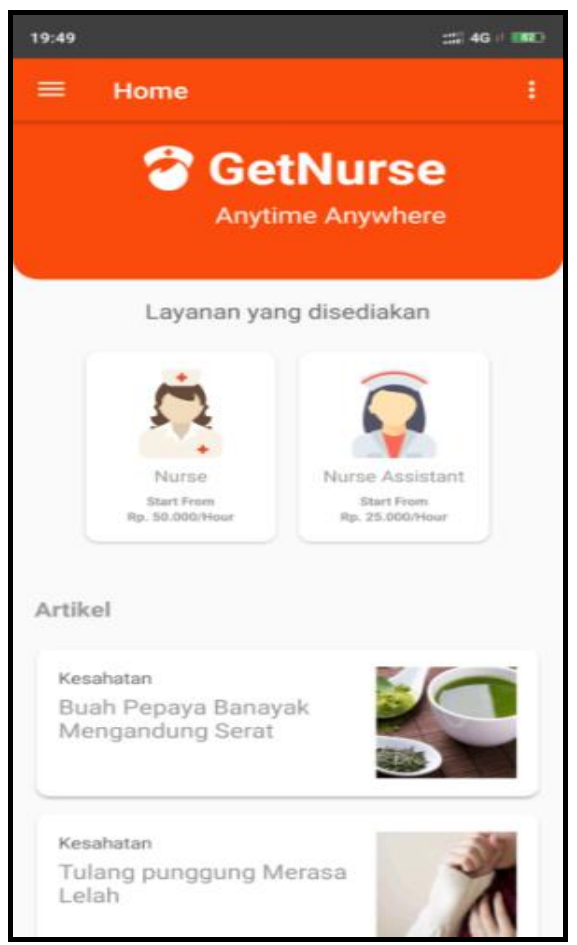

Gambar 7 Halaman Utama 
Pada gambar 7 diatas, pasien dapat memilih 2 layanan yaitu nurse dan nurse assistant. Serta terdapat artikel kesehatan yang dapat dibaca oleh pasien.

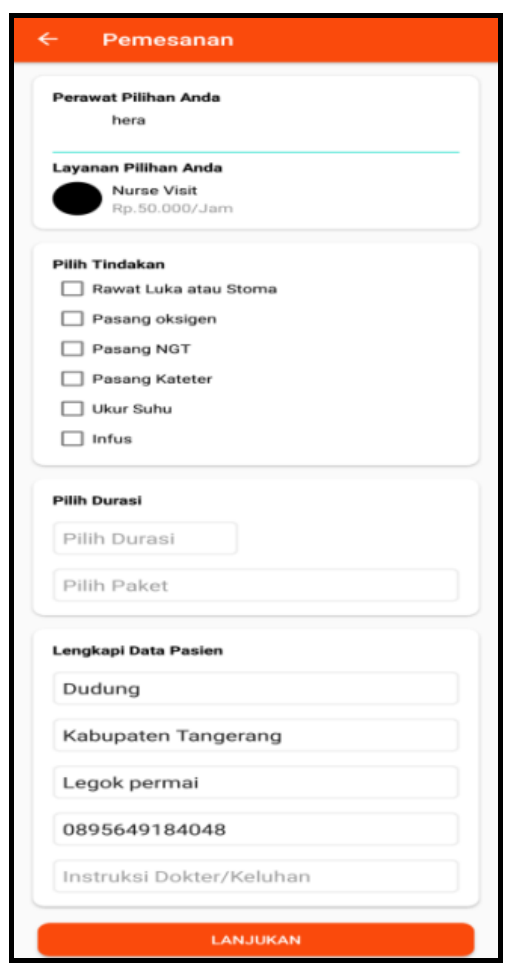

Gambar 8 Halaman Pemesanan

Pada gambar 8 diatas. pasien dapat memilih tindakan, memilih durasi dan paket serta menginput keluhan. Jika sudah, pasien akan diarahkan ke halaman pembayaran.

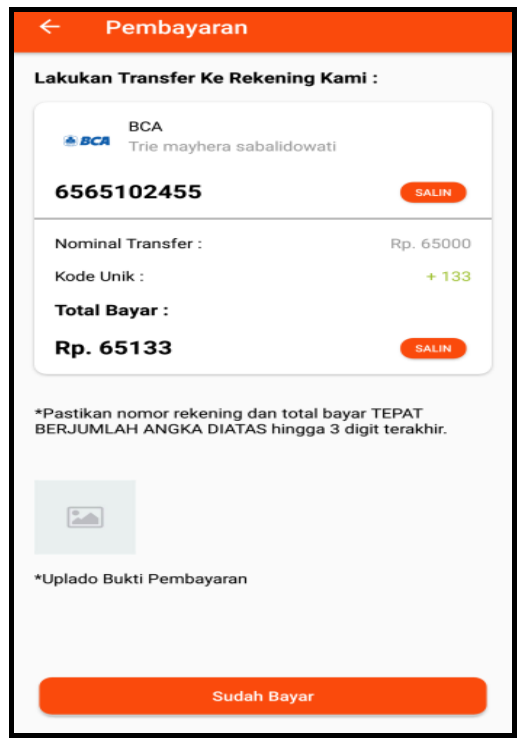

Gambar 9 Halaman Pembayaran

Pada gambar 9 diatas. terdapat no rekening tujuan transfer dan nominal pembayaran. Jika pasien sudah melakukan transfer maka dapat mengupload foto bukti pembayaran. 


\subsection{Usability Testing}

Tabel 1. Usability Testing Aplikasi Get Nurse

\begin{tabular}{|c|c|c|c|c|}
\hline Test Scenario & Test Case & $\begin{array}{c}\text { Expected } \\
\text { Result }\end{array}$ & Result & Status \\
\hline Login User & $\begin{array}{ll}\text { 1. } & \text { Ke login page } \\
\text { 2. } & \text { Input email } \\
\text { 3. } & \text { Input password }\end{array}$ & $\begin{array}{l}\text { Menampilkan } \\
\text { halaman utama }\end{array}$ & Sesuai & Pass \\
\hline Register User & $\begin{array}{l}\text { 1. Ke register page } \\
\text { 2. Input nama lengkap } \\
\text { 3. Input username } \\
\text { 4. Input password }\end{array}$ & $\begin{array}{l}\text { Menyimpan data } \\
\text { ke database dan } \\
\text { menampilkan } \\
\text { pesan registrasi } \\
\text { berhasil }\end{array}$ & Sesuai & Pass \\
\hline $\begin{array}{l}\text { Memilih } \\
\text { Layanan }\end{array}$ & $\begin{array}{l}\text { 1. Pasien memilih menu } \\
\text { nurse } \\
\text { 2. Pasien memilih menu } \\
\text { nurse assistance }\end{array}$ & $\begin{array}{l}\text { Menampilkan } \\
\text { layanan yang } \\
\text { disediakan }\end{array}$ & Sesuai & Pass \\
\hline $\begin{array}{l}\text { Pemesanan } \\
\text { Layanan }\end{array}$ & $\begin{array}{l}\text { 1. Pasien mengklik } \\
\text { tombol pesan } \\
\text { 2. Pasien memilih } \\
\text { tindakan medis } \\
\text { 3. Pasien memilih durasi } \\
\text { layanan } \\
\text { 4. Pasien mengisi form } \\
\text { keluhan } \\
\text { 5. Pasien mengklik } \\
\text { tombol lanjutkan }\end{array}$ & $\begin{array}{l}\text { Menampilkan } \\
\text { pesan konfirmasi } \\
\text { pemesanan dan } \\
\text { dialihkan ke } \\
\text { halaman } \\
\text { pembayaran }\end{array}$ & Sesuai & Pass \\
\hline $\begin{array}{l}\text { Konfirmasi } \\
\text { Pembayaran }\end{array}$ & $\begin{array}{l}\text { 1. Pasien mentransfer } \\
\text { uang ke rekening } \\
\text { yang telah ditentukan } \\
\text { 2. Pasien mengupload } \\
\text { bukti pembayaran } \\
\text { 3. Pasien mengklik } \\
\text { tombol sudah bayar }\end{array}$ & $\begin{array}{l}\text { Menampilkan } \\
\text { pesan } \\
\text { pembayaran } \\
\text { berhasil }\end{array}$ & Sesuai & Pass \\
\hline $\begin{array}{l}\text { Melihat } \\
\text { Artikel }\end{array}$ & $\begin{array}{l}\text { 1. User mengklik menu } \\
\text { artikel }\end{array}$ & $\begin{array}{l}\text { Menampilkan } \\
\text { artikel kesehatan } \\
\text { dan } \\
\text { penjelasannnya }\end{array}$ & Sesuai & Pass \\
\hline $\begin{array}{l}\text { Melihat } \\
\text { History } \\
\text { Pemesanan }\end{array}$ & $\begin{array}{l}\text { 1. User mengklik menu } \\
\text { history }\end{array}$ & $\begin{array}{l}\text { Menampilkan } \\
\text { history } \\
\text { pemesanan dan } \\
\text { status pemesanan }\end{array}$ & Sesuai & Pass \\
\hline Logout User & $\begin{array}{l}\text { 1. User mengklik } \\
\text { tombol logout } \\
\text { 2. Mengklik tombol yes }\end{array}$ & $\begin{array}{l}\text { Menampilkan } \\
\text { pesan konfirmasi } \\
\text { logout, jika ya } \\
\text { maka keluar } \\
\text { aplikasi, jika tidak } \\
\text { maka user masih } \\
\text { berada di aplikasi }\end{array}$ & Sesuai & Pass \\
\hline
\end{tabular}




\section{KESIMPULAN}

Saat ini sistem pelayanan kesehatan masih banyak dilakukan secara manual, yakni masyarakat harus mendatangi rumah sakit atau klinik, padahal dampak dari pandemi ini membuat masyarakat khawatir keluar rumah karena khawatir terpapar virus corona. Penulis menggunakan metode analisis BMC (Business Model Canvas) untuk menganalisa, serta Unified Modeling Language (UML) untuk menggambarkan pemodelan sistem dengan tools Flowchart Maker \& Online Diagram Software. Dalam perancangan sistem, peneliti menggunakan bahasa Kotlin dengan arsitektur MVP (Model-View-Presenter), serta API dengan bahasa PHP. Dalam metode pengujiannya penulis menggunakan metode Usability Testing.

\section{SARAN}

Dengan platform berbasis mobile di harapkan pelayanan kesehatan khususnya ditengah pandemi virus corona ini dapat di tingkatkan lagi supaya lebih mempermudah masyarakat dalam menerima layanan kesehatan khususnya layanan kesehatan dirumah (Homecare) sehingga meminimalisir dampak penyebaran virus corona di tengah masyarakat. Serta dapat dilakukan pengembangan agar aplikasi yang telah dibuat bisa lebih bagus, seperti integrasi payment gateway sehingga mempermudah sistem pembayaran.

\section{DAFTAR PUSTAKA}

[1] Sari, H.P., \& Tsarina, M. (2020, September 11). Kasus Covid-19 di Indonesia Capai 210.940. nasional.kompas.com/read/2020/09/11/15160881/update-bertambah-3737-kasuscovid-19-di-indonesia-capai-210940, diakses tgl 1 oktober 2020.

[2] Santoso, S., Soleh, O., \& Humaeroh, S. 2020. Aplikasi Jendela Akademik Sebagai Media Komunikasi Orangtua Dan Sekolah Pada BP2IP Tangerang. Jurnal SENSI. Vol. 6, No. 1.

[3] Junaidi, J., Nurbaiti, T., \& Agustini, T. 2020. Sistem Monitoring Transaksi Customer Berbasis Web Pada MNC Media Play. Jurnal SENSI, Vol. 6, No. 2.

[4] Yuliyana, T., Arthana, I.K.P., \& Agustini, K. 2019. Usability Testing Pada Aplikasi POTWIS. Jurnal Sains \& Teknologi Ganesha, Vol. 8, No.1.

[5] Harsiti., Tedi., Purnamasari, M., \& Dwiyatno, S. 2016. Rancang Bangun Aplikasi E-Health Untuk Peningkatkan Pelayanan Kesehatan Pada Puskesmas Kibin. Jurnal Sistem Informasi, Vol. 3, 15-18.

[6] Sari, Y., Kurniawan, A., \& Suhandono, E. 2020. Rancang Bangun Aplikasi Homecare Ibu Dan Anak Berbasis Android. Jurnal TEKINFO, Vol. 21, No. 2, 105-112.

[7] Sambuaga, J.H., Rindengan, Y.D.Y., \& Sambul, Alwin. 2017. Perancangan E-Health Kota Cerdas. Jurnal Teknik Informatika, Vol. 11, No. 1.

[8] Istifada, R., Sukihananto., \& Laagu, M.A. 2017. Pemanfaatan Teknologi Telehealth Pada Perawat Di Layanan Homecare. Nursing Current, Vol. 5, No. 1, 51-61. 